\title{
Dynamics of the plankton communities of the Lazarev Sea (Southern Ocean) during seasonal ice melt
}

\author{
P. W. Froneman ${ }^{1, *}$, E. A. Pakhomov ${ }^{1}$, R. Perissinotto ${ }^{2}$, R. K. Laubscher ${ }^{1}$, \\ C. D. McQuaid ${ }^{1}$ \\ 'Southern Ocean Group, Department of Zoology and Entomology, Rhodes University, PO Box 94, Grahamstown 6140 , \\ South Africa \\ ${ }^{2}$ Department of Zoology, University of Fort Hare, Private Bag X1314, Alice 5770, South Africa
}

\begin{abstract}
Size-fractioned primary production and zooplankton grazing impact were estimated along a repeat grid during seasonal ice melt in the Lazarev Sea aboard the MV 'SA Agulhas' (voyage 77) in austral summer (December/January) 1994-1995. During the survey, the phytoplankton size composition shifted from a communuty dominated by nano- and picophytoplankton $(<20 \mu \mathrm{m})$ during the first grid to one dominated by microphytoplankton $(>20 \mu \mathrm{m})$ during the second grid. Total areal production during the first grid was generally dominated by nanophytoplankton and ranged between 133 and $356 \mathrm{mg} \mathrm{C} \mathrm{m} \mathrm{C}^{-2}$. During the second grid survey, total areal production was higher, ranging between 263 and $400 \mathrm{mg} \mathrm{C} \mathrm{m}^{-2} \mathrm{~d}^{1}$ Protozoan grazing removed between 0.5 and $31 \%$ of the initial phytoplankton stock or between 33 and $94 \%$ of the potential phytoplankton production per day during the first grid, and between 0.5 and $8 \%$ of the initial phytoplankton stock or between 9 and $25 \%$ of the potential phytoplankton production per day during the second grid. The grazing impact of meso- and macrozooplankton during the first grid corresponded to $<0.5 \%$ of chlorophyll stock or $<23 \%$ of the daily primary production. Dunng the second grid, the grazing impact of meso-and macrozooplankton was higher, removing on average $1.12 \%$ of integrated chlorophyll or $28.7 \%$ of daily production. These results suggest that the partitioning of carbon between the various size classes of zooplankton during seasonal ice retreat is largely determined by the size structure of the phytoplankton.
\end{abstract}

KEY WORDS: Southern Ocean - Marginal Ice Zone Phytoplankton production - Zooplankton grazing impact

\section{INTRODUCTION}

The fate of photosynthetically fixed carbon in marine environments can dramatically affect the magnitude of particulate flux, and hence the efficiency of the biological pump in the drawdown of atmospheric $\mathrm{CO}_{2}$ (Longhurst \& Harrison 1989, Longhurst 1991). Although sinking of dead or senescent phytoplankton cells contributes significantly to the magnitude of carbon flux (Schnack 1985, von Bodungen et al. 1986, Michaels \& Silver 1988), grazing by macro- and meso-

•E-mail: zopf@warthog.ru.ac.za zooplankton represents the primary biological route for the transfer of organic carbon from the surface waters to the interior of the ocean. The extent of carbon flux through grazers is strongly determined by the community structure of the consumers and the subsequent partitioning of photosynthetically fixed carbon (Michaels \& Silver 1988, Roman et al. 1993, Froneman \& Perissinotto 1996a, b). Large grazers such as macroand mesozooplankton generally contribute to particle flux through the production of large, compact and fast sinking faecal pellets which have a high carbon content (Schnack 1985, von Bodungen 1986, Cadee et al. 1992, Gonzalez 1992a, Fortier et al. 1994). Carbon flux beneath the zone of regeneration is further enhanced 
as many of the larger herbivores undertake vertical migrations from the surface waters where they feed to below the zone of regeneration (Fortier et al. 1994). Production originating in the surface waters is, therefore, transported to depth.

In contrast, phytoplankton production entering the microbial loop (which comprises bacteria, small phytoplankton and protozoa) contributes less to particulate flux because the close coupling between protozoans and bacteria results in the recycling of nutrients within the zone of regeneration (Sherr \& Sherr 1988). Furthermore, protozoans produce small faecal pellets (minipellets) which remain in suspension for long periods (Nöthig \& von Bodungen 1989, Elbrächter 1991, Gonzalez 1992b) and also protozoans do not undergo vertical migrations. Nutrients contained within these organisms are not transported below the zone of regeneration. As a consequence, there is little material available for direct export to the deep ocean.

A major feature of the Southern Ocean is sea ice which in winter may extend as far north as $56^{\circ} \mathrm{S}$ (Sullivan et al. 1993). Generally associated with the seasonal retreat of ice are phytoplankton blooms which are thought to result from the release of epontic cells during sea ice melt and increased in situ phytoplankton associated with increased water column stability imparted by ice melt and reduced wind stress (Smith \& Nelson 1986, El-Sayed 1988, Jacques 1989, Smith \& Sakshaug 1990). Models of the Marginal Ice Zone (MIZ) phytoplankton production suggest that while the existence of vertical stability for more than $1 \mathrm{wk}$ is essential for the development of persistent phytoplankton blooms (Mitchell \& Holm-Hansen 1991), this is not the only condition required to allow high biomass development (Lancelot et al. 1993). Trace metal deficiency such as iron (Martin et al. 1990) or grazing by zooplankton may limit phytoplankton growth in the MIZ (Lancelot et al. 1993).

It is well documented that grazing by larger zooplankton may dramatically affect the species composition and distribution of phytoplankton in the Southern Ocean (Granéli et al. 1993, Perissinotto 1992, Perissinotto \& Pakhomov in press). Indeed, grazing by large zooplankton may at times exceed $100 \%$ of the daily phytoplankton production (Hansen et al. 1990, Ward et al. 1995, Perissinotto \& Pakhomov in press). Recently, microzooplankton $(20-200 \mu \mathrm{m})$ have been shown to play an important role in the energy dynamics of the Antarctic pelagic system (Garrison et al. 1993, Burkill et al. 1995, Froneman \& Perissinotto 1996). In particular, in regions dominated by small phytoplankton cells, microzooplankton often represent the most important grazers of phytoplankton production (Garrison et al. 1993, Burkill et al. 1995, Froneman \& Perissinotto 1996a). A study conducted in the MIZ of the Weddell
Sea has shown that grazing by protozoans may determine the magnitude of development of an ice edge bloom dominated by small phytoplankton cells (Lancelot et al. 1993). These facts suggest that the fate of phytoplankton carbon in the MIZ will be determined by the size composition of the phytoplankton assemblages.

Production associated with the retreating ice has been estimated to account for $-40 \%$ of the total production south of the Antarctic Polar Front (Smith \& Nelson 1986). The factors controlling phytoplankton production and subsequent partitioning of carbon between the various size classes of zooplankton in this region is of particular interest for determination of the total energy budget of the Southern Ocean. The aim of this study was to investigate the plankton dynamics in the MIZ of the Lazarev Sea during seasonal ice melt, in austral summer.

\section{MATERIALS AND METHODS}

Size-fractioned primary production and zooplankton grazing experiments were conducted aboard the MV 'SA Agulhas' during a repeat grid survey in the Marginal Ice Zone of the Lazarev Sea during the fourth South African Antarctic Marine Ecosystem Study (SAAMES IV) cruise in austral summer (14 December/ 15 January) 1994-1995 (Fig. 1).

Primary production studies. Estimates of size-fractioned phytoplankton production rates were carried out following the JGOFS protocol (JGOFS 1990). Water samples were collected with a $12 \times 81$ Niskin bottle rosette from depths corresponding to the 100 , $50,25,10,5$ and $1 \%$ subsurface light levels. Replicate $250 \mathrm{ml}$ aliquots in polycarbonate bottles were collected from separate Niskin bottles from each light level. All manipulations were carried out under low-light conditions to prevent light shock. $\mathrm{NaH}^{14} \mathrm{CO}_{3}$ (Amersham) was added to each polycarbonate bottle to give a specific activity of $25 \mu \mathrm{Ci} \mathrm{ml}{ }^{-1}$. Non-specific ${ }^{14} \mathrm{C}$-uptake and organic ${ }^{14} \mathrm{C}$ contamination of stock were accounted for using 2 time zero bottles $(250 \mathrm{ml}$ ) corresponding to the 50 and $10 \%$ light levels, from which $1 \mathrm{ml}$ alıquots were removed and acidified immediately. Samples were then incubated for $24 \mathrm{~h}$ in a on-deck incubator cooled with running surface water under simulated light conditions corresponding to depth of collection.

At the end of the incubation, three $60 \mathrm{ml}$ aliquots from each incubation bottle were filtered through $(<5 \mathrm{~cm} \mathrm{Hg}) 20 \mu \mathrm{m}$ Nitex, $2.0 \mu \mathrm{m}$ and $0.2 \mu \mathrm{m}$ Nuclepore polycarbonate filters. Each filter was placed in a scintillation vial and $0.25 \mathrm{ml} 3 \mathrm{~N} \mathrm{HCl}$ added. The vials were then placed on a shaker for a period of $1 \mathrm{~h}$ after which 
$0.25 \mathrm{ml} 3 \mathrm{~N} \mathrm{NaOH}$ was added to neutralise the solution. $10 \mathrm{ml}$ of scintillation fluor was then added to each vial, which was then placed in a dark room for $12 \mathrm{~h}$. Total radioactivity was determined from a $0.25 \mathrm{ml}$ aliquot taken from each incubation bottle, which was then treated as above. Radioactivity (DPM) was then counted with a Beckman LS 133 scintillation counter. The DPM values were converted to daily productivity rates using the following equation:

Production $\left(\mathrm{mg} \mathrm{C} \mathrm{m} \mathrm{m}^{-3} \mathrm{~d}^{-1}\right)=$

$(\mathrm{SDPM} / V) \times\left(W \times 0.25 \times 10^{3} / \mathrm{TDPM}\right) \times(1.05 / T)$

where SDPM is the DPM in filtered sample; $V$ is the volume of filtered sample; TDPM is the total radioactivity of ${ }^{14} \mathrm{C}(0.25 \mathrm{ml})$; $T$ is time (days); 1.05 is the correction factor for the lower uptake of ${ }^{14} \mathrm{C}$ compared to ${ }^{12} \mathrm{C} ; 0.25 \times 10^{3}$ is the conversion of pipette volume to litres; $W$ is the dissolved inorganic carbon concentration in samples.

Areal productivity and chlorophyll a (chl a) concentrations in the euphotic zone (depth to $1 \%$ of surface irradiance) were then obtained by trapezoidal integration.

Chl a and phaeopigments were extracted in $90 \%$ acetone and their concentrations calculated from fluorescence readings on a Turner Model 111 fluorometer (Parsons et al. 1984) calibrated with pure chl a (Sigma). Three size classes of phytoplankton, micro$(200-20 \mu \mathrm{m})$, nano- $(20-2.0 \mu \mathrm{m})$ and picophytoplankton $(2.0-0.45 \mu \mathrm{m})$, were obtained by filtration of separate subsamples.

Water samples were also taken from the Niskin bottles for the determination of nitrate and silicate concentrations using a Technicon Autoanalyzer II, following the methods of Strickland \& Parsons (1968) and Mostert (1983). Dissolved inorganic carbon was measured using the potentiometric titration method of Almgren et al. (1983). Conductivity, temperature and depth were measured using a Neil Brown Mk III CTD attached to the rosette sampler. Daily surface photosynthetic active radiation (400 to $700 \mathrm{~nm}$ ) was measured using a Li Cor $4 \pi$ spherical quantum sensor (LI1935A). Means for every 10 to $15 \mathrm{~min}$ were logged throughout the day by a Li Cor Data Logger (LI-1000). The subsurface light field was measured with the same instrument and used to calculate the sampling depths. Thermocline depths were estimated from CTD thermal traces and then used to estimate mixed-layer depths. Wind speed was logged continuously by the ship's anemometer. Data were averaged over a $24 \mathrm{~h}$ period to obtain the mean daily wind speed.

Microplankton community structure and protozoan grazing. The protozoan $(2-200 \mu \mathrm{m})$ grazing impact was estimated from water samples collected with 81 Niskin bottles from the surface and the chlorophyll maximum, determined from the aquatracker attached to the CTD. For each experiment, 20 I polyethylene carboys were filled with the collected seawater. The water in the carboys was then gently passed through a $200 \mu \mathrm{m}$ mesh to isolate the microzooplankton community. Particle-free water was obtained by passing surface water lobtained using a shipboard metal-free Iwaki Magnetic Pump operated at a flow rate of $\sim 51$ min $^{-1}$ ) through a $0.2 \mu \mathrm{m}$ Milli $Q$ (Millipore) filtration system. Dilution series in ratios of 1:0, 3:1, 1:1 and $1: 3$ of unfiltered to filtered seawater were then prepared in 2 l polyethylene bottles. Samples from the dilution series were incubated on deck for $24 \mathrm{~h}$ in perspex incubators cooled with running surface water and screened with shade cloth (neutral spectral transmission) to simulate light intensity at the depth of collection.

Before the incubations were begun, water samples ( $250 \mathrm{ml}$ ) were taken for the initial chl a concentration The bottles were sampled again at the end of the incubation to determine the final chl a concentrations. Chl a concentrations were determined fluorometrically
Fig. 1 Location of the study area and positions of the stations during the $(A)$ first and (B) second grid surveys conducted in the Marginal Ice Zone (MIZ) of the Lazarev Sea during austral summer (December/January) 1994-1995
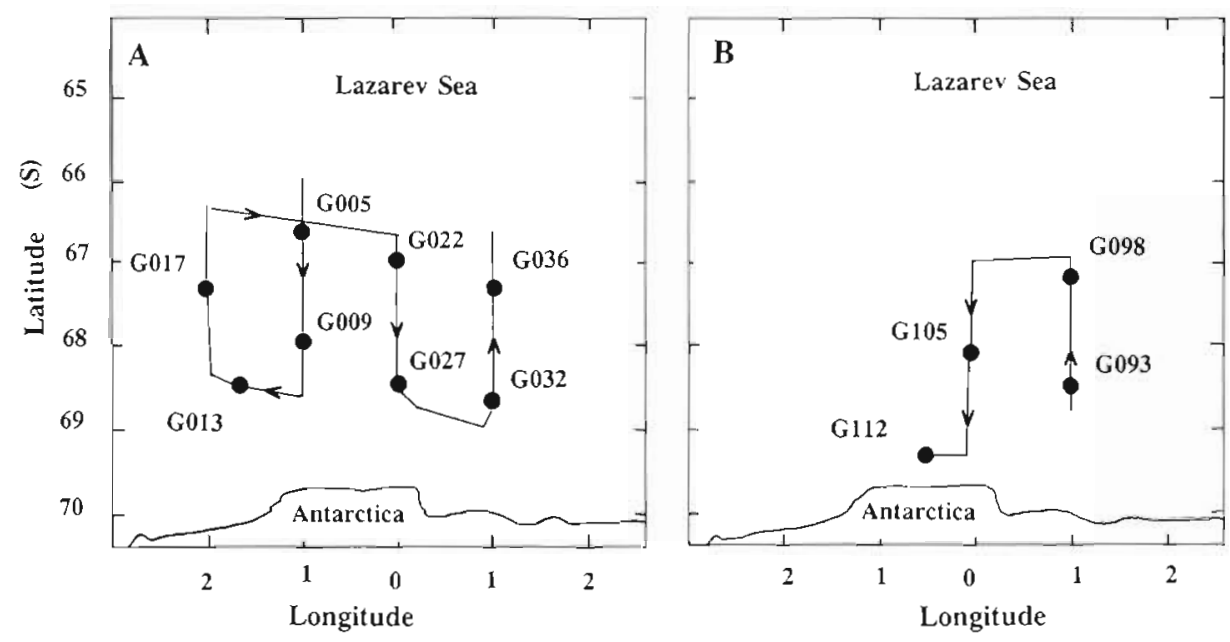
(Turner 111 fluorometer) after extraction in $100 \%$ cold methanol for 6 to $12 \mathrm{~h}$ (Holm-Hansen \& Riemann 1978). A previous study conducted by the authors showed that the extraction efficiency of methanol and acetone were not significantly different $(p>0.05)$.

To identify and enumerate the various components of the microplankton communities at each grazing station, a $250 \mathrm{ml}$ sample of natural seawater was passed gently through a $200 \mu \mathrm{m}$ mesh and fixed with $10 \%$ Lugol's solution (Leakey et al. 1994, Stoecker et al. 1994). For the taxonomic analysis of the microphytoplankton standing stock, a $20 \mu \mathrm{m}$ mesh filtration unit (Berman \& Kimor 1983) was connected to the pump outlet and a constant volume of $20 \mathrm{l}$ of seawater was filtered at each station. The phytoplankton retained by the filter was preserved in $2 \%$ buffered formalin. The water samples were then examined using the Utermöhl settling technique, employing a Nikon-TMS inverted microscope operated at $400 \times$ magnification (Reid 1983). A minimum of 500 cells or 100 fields were counted for each sample.

The apparent growth rate of chl a in each bottle was calculated using the exponential model of Landry \& Hassett (1982):

$$
P_{t}=P_{0} \mathrm{e}^{\mid k-g) t}
$$

where $P_{t}$ is the chl a concentration at time $t_{i} P_{0}$ is the initial chl a concentration; $k$ and $g$ are the instantaneous algal growth and microzooplankton grazing coefficients, respectively. The coefficients were determined from linear regression analysis ( $95 \%$ confidence limits) between dilution factor and apparent growth rate of chl $a$ in each bottle using the computer program Statgraphics Version 5.0 (Statgraphics 1992). Both $g$ and $k$ were used to calculate the grazing loss of potential production, while only the grazing mortality coefficient $(g)$ was employed to calculate the daily loss of initial standing stock.

Correlation analysis was performed to identify possible relationships between grazing rate, temperature and chl a. Grazing rate data, expressed as \% initial standing stock and potential primary production removed per day, were transformed using an arcsin transformation (Sokal \& Rolhf 1969), while chlorophyll concentration values were transformed using the factor: $\log (x+1)$ (Legendre \& Legendre 1983). The computer package Statgraphics Version 5.0 was again used for this analysis.

Meso- and macrozooplankton community structure and grazing impact. Meso- and macrozooplankton community structure and the grazing impact of the 7 most common taxa (in terms of abundance) were determined from samples collected with oblique net tows (500 $\mu \mathrm{m}$ Bongo nets) carried out between 300 and $0 \mathrm{~m}$. Half the sample collected was immediately fixed in $5 \%$ buffered formalin for the taxonomic analysis of the zooplankton community while the other half was used to estimate meso- and macrozooplankton grazing impact on phytoplankton using the in situ gut fluorescence technique (Perissinotto 1992, Perissinotto \& Pakhomov 1996).

The gut evacuation experiments consisted of in vitro incubations in particle-free water lobtained by passing surface water through a $0.2 \mu \mathrm{m}$ Milli $\mathrm{Q}$ filtration system) of freshly caught specimens of the 7 most common species in 201 polyethylene containers. Prior to the incubations, 5 to 10 specimens of each species were processed to monitor initial gut pigment concentrations. The incubation of specimens ranged from 6 to $24 \mathrm{~h}$, with gut fluorescence measured at 5 to $20 \mathrm{~min}$ intervals for the first 1 to $2 \mathrm{~h}$ and every 0.5 to $4 \mathrm{~h}$ thereafter until the end of the experiment. Three to five specimens were collected for each time interval measurement. Gut evacuation rates $\left(K, \mathrm{~h}^{-1}\right)$ were then derived from the slope of the regression of the natural logarithm of gut pigment content versus time (Perissinotto \& Pakhomov 1996). At stations where the gut evacuation rates $(K)$ were not available, the average values for that species along each grid were employed.

To estimate gut pigment destruction efficiency $\left(b^{\prime}\right)$, freshly caught animals were incubated in particle-free seawater to which charcoal particles $(<100 \mu \mathrm{m})$ were added for 6 to $24 \mathrm{~h}$ to allow the animals to empty their guts of pigments (Perissinotto \& Pakhomov 1996). Specimens (5 copepods and 1 to 2 euphausiids or salps per jar) were then incubated for 1 to $2 \mathrm{~h}$ in $1 \mathrm{l}$ polyethylene containers containing natural seawater. The gut pigment destruction efficiency was estimated using the 2 compartment (phytoplankton and grazer) pigment budget approach. A comparison of the pigment budgets in the control (without grazers) and experimental treatment was then carried out. Any significant loss in the pigment budget from the experimental treatment (with grazers) was then attributed to gut destruction of phytoplankton pigments (Perissinotto \& Pakhomov 1996). Previous studies conducted in the Antarctic have demonstrated that the gut passage time of copepods may be $<1 \mathrm{~h}$ suggesting that the gut destruction efficiency of the copepods may have been overestimated during this study. However, since no faecal pellets were observed at the end of the incubations, the over-estimation appears to have been negligible. At stations where gut pigment destruction efficiency experiments were not conducted, an average value of 0.5 was employed (Perissinotto 1992).

In all the experiments, gut pigments were extracted in $10 \mathrm{ml}$ polyethylene tubes ( 1 ind. per tube for macrozooplankton; 3 to 5 ind. for mesozooplankton) with 5 to $7 \mathrm{ml}$ of $100 \%$ methanol and stored at $-20^{\circ} \mathrm{C}$ for $12 \mathrm{~h}$. After centrifugation at $5000 \mathrm{rpm}(1745 \times \mathrm{g})$, the pig- 
ment content of the methanol was measured before and after acidification using a Turner Model 111 fluorometer (Mackas \& Bohrer 1976). Pigment contents were then expressed in terms of total pigments per individual and calculated according to Strickland \& Parsons (1968) as modified by Conover et al. (1986). Where the chlorophyll:phaeopigment ratio in the gut content was higher than 0.25 , total pigment levels were corrected according to Baars \& Helling (1985).

Daily ingestion rates $\left(I\right.$, ng pigm. ind $\left.{ }^{-1} \mathrm{~d}^{-1}\right)$ were then estimated from the relation of Perissinotto 1992:

$$
I=K G /\left(1-b^{\prime}\right)
$$

where $G$ is an integrated value (over $24 \mathrm{~h}$ period, assuming a linear decay in gut pigment) of gut pigments (ng pigm. ind ${ }^{-1}$ ), $K$ is the gut evacuation rate constant $\left(\mathrm{h}^{-1}\right)$, and $b^{\prime}$ is efficiency of gut pigment destruction during digestion.

In order to estimate the community grazing impact, zooplankton abundance data were combined with the individual ingestion rates. To convert chl a concentrations (chl) into autotrophic carbon (C), the empirical equation of Hewes et al. (1990): $C=80 \mathrm{chl}^{0.6}$ was used. The grazing impact was then expressed as \% integrated phytoplankton stock and \% daily primary production consumed per day.

\section{RESULTS}

\section{Oceanographic conditions}

A summary of the initial experimental conditions along the repeat grid is shown in Table 1 . During the first grid survey, pack-ice covered between 5 and $>90 \%$ of the sea surface. The general trend was an increase in sea ice from west to east and from north to south. Sea surface temperatures ranged between -1.0 and $-1.65^{\circ} \mathrm{C}$ (Table 1). Although a well-developed halocline was observed, no thermocline was evident in the upper water column (Fig. 2). The pattern of nutrient distribution in the upper euphotic zone was similar for silicate and nitrate concentrations. The general trend was an increase in the concentrations of the 2 nutrients with an increase in depth. Silicate concentrations were always $>75 \mu \mathrm{mol} \mathrm{l}^{-1}$, while nitrate concentrations exceeded $25 \mu \mathrm{mol} \mathrm{l^{-1 }}$ at all stations.

During the second grid survey, no ice was evident (Table 1). Sea surface temperatures had increased, ranging between -0.32 and $0.29^{\circ} \mathrm{C}$, suggesting that summer capping of colder winter waters with fresher warmer waters had occurred (Table 1). The upper water column appeared to be strongly stratified with a well-developed halocline and a thermocline evident in the upper $50 \mathrm{~m}$ (Fig. 3). The patterns of nutrient distribution during the second grid were similar to the first grid, with an increase in concentrations of silicate and nitrate with depth. The concentrations of silicate and nitrate were, however, lower. Silicate and nitrate concentrations were $\geq 60$ and $\geq 20 \mu \mathrm{mol} \mathrm{l}^{-1}$, respectively.

\section{Phytoplankton and microplankton community structure}

During the investigation, the $<20 \mu \mathrm{m}$ chlorophyll fraction was always dominated by small diatoms of the genera Nitzschia and Chaetoceros and unidentified nanoflagellates. The microphytoplankton (>20 $\mu \mathrm{m}$ ) were numerically dominated by ice-associated chainforming species of the genera Chaetoceros and Nitzschia and larger diatoms such as Corethron criophilum.

Table 1 Summary of initial environmental conditions during the repeat grid survey conducted in the MIZ of the Lazarev Sea during late austral summer (December/January) 1994-1995. PAR: photosynthetically active radiation

\begin{tabular}{|c|c|c|c|c|c|c|}
\hline Station & $\begin{array}{l}\text { Sea surface } \\
\text { temp. }\left({ }^{\circ} \mathrm{C}\right)\end{array}$ & $\begin{array}{c}\% \\
\text { ice cover }\end{array}$ & $\begin{array}{c}\text { PAR } \\
\left(\mu E \mathrm{~m}^{-2} s^{-1}\right)\end{array}$ & $\begin{array}{l}\text { Wind speed } \\
\text { (knots) }\end{array}$ & Cloud cover & Sea state \\
\hline \multicolumn{7}{|l|}{ Grid 1} \\
\hline G005 & -1.12 & $<5$ & 913 & 18.5 & $8 / 8$ & 1 \\
\hline Go09 & -1.11 & 30 & 959 & 22.6 & $8 / 8$ & 1 \\
\hline G013 & -1.63 & $40-50$ & 3184 & 18.9 & $2 / 8$ & 2 \\
\hline G017 & -1.65 & $40-50$ & 952 & 15.3 & $8 / 8$ & 1 \\
\hline G022 & -1.29 & 30 & 1605 & 16.6 & $8 / 8$ & 2 \\
\hline G027 & -1.49 & $>90$ & 1105 & 10.4 & $8 / 8$ & 2 \\
\hline G032 & -1.44 & $>90$ & 1113 & 10.4 & $8 / 8$ & 1 \\
\hline G036 & -1.00 & 25 & 625 & 12.4 & $8 / 8$ & 1 \\
\hline \multicolumn{7}{|l|}{ Grid 2} \\
\hline G093 & -0.32 & 0 & 939 & 28.3 & $8 / 8$ & 4 \\
\hline G098 & -0.14 & 0 & 1221 & 22.2 & $8 / 8$ & 3 \\
\hline G105 & 0.00 & 0 & 725 & 17.3 & $8 / 8$ & 3 \\
\hline G112 & 0.29 & 0 & 541 & 8.8 & $8 / 8$ & 1 \\
\hline
\end{tabular}



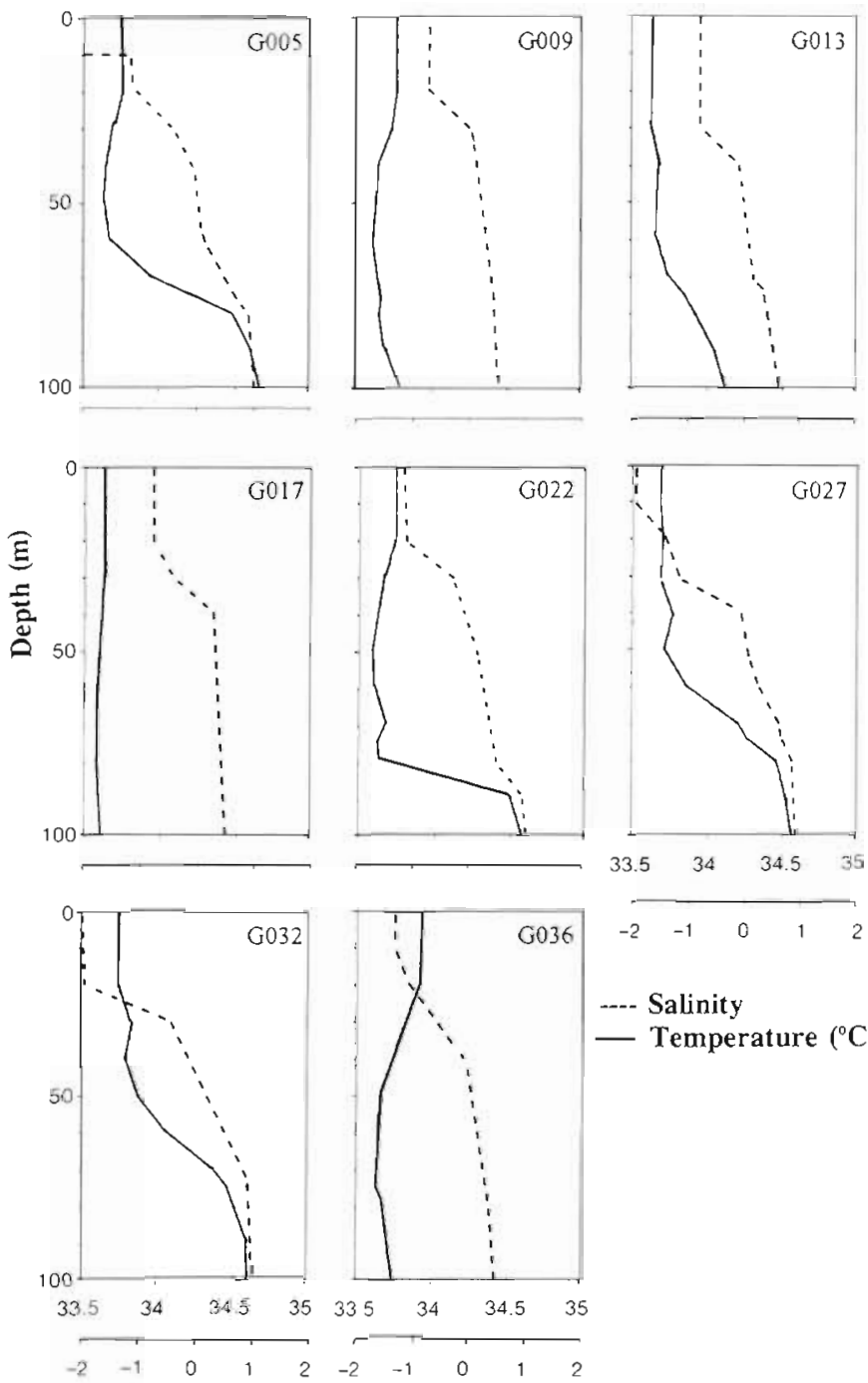

Fig. 2. Temperature and salinity profiles at stations occupied durnng the first grid survey conducted in December 1994

The microplankton assemblages during the first grid were entirely dominated by protozoans with densities ranging between 2550 and 3650 cells $l^{-1}$ (Table 2). The ciliates, comprising aloricates and tintinnids, numerically dominated with cell densities ranging from 1750 to 2600 cells $~^{-1}$. Aloricate forms constituted the main component of the ciliate group, with densities ranging

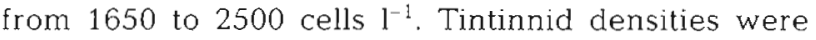
always $<150$ cells $l^{-1}$. Among the flagellates, members of the genus Protoperidinium were the most abundant

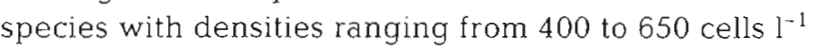
(Table 2). Also well represented amongst the dinoflagellates were species of the genera Amphisolenia, Amphidinium and Gonyaulax. Densities of these species were, however, always $<250$ cells $l^{-1}$.

Along the second grid, the microplankton were again dominated by protozoans with densities ranging between 1850 and 2850 cells $\mathrm{I}^{-1}$ (Table 2). As in

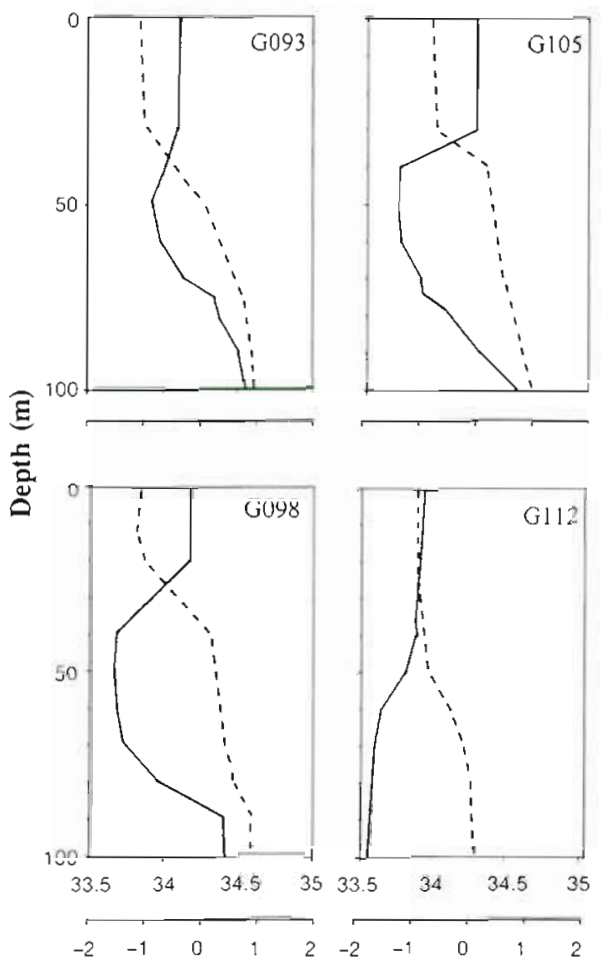

Fig. 3. Temperature and salinity profiles at stations occupied during the second grid survey conducted in January 1995

the previous grid, ciliates comprising aloricate (densities: 1050 to 1700 cells $\mathrm{l}^{-1}$ ) and tintinnids (densities $<150$ cells $1^{-1}$ ) numerically dominated the total stock. Among the dinoflagellates, species of the genera Protoperidinium were again the most numerous, with cell densities ranging from 250 to $550 \mathrm{l}^{-1}$. Also well represented among the dinoflagellates were species of the genera Amphidinium and Gonyaulax. Densities of these species were generally $<200$ cells $I^{-1}$ (Table 2).

\section{Macro- and mesozooplankton community structure}

The 7 most abundant macro- and mesozooplankton species comprised $>80 \%$ of total zooplankton along the repeat grid and are shown in Table 3 . Total abundances along the first grid ranged between 2.2 and 12.5 ind $\mathrm{m}^{-3}$ (Table 3). Among the zooplankton, copepods represented by Rhincalanus gigas, Calanus propinquus, Calanoides acutus and Metridia gerlachei were the most numerous contributing between 79 and $98 \%$ of the total (Table 3 ). C. acutus and $M$. gerlachei were the most abundant species. Densities of the larger zooplankton were always $<0.5$ ind $\mathrm{m}^{-3}$ and were generally numerically dominated by the tunicate Salpa thompsoni (Table 3). 
Table 2. Microplank.ton species composition and abundances (cells l') along the 2 grids occupied

\begin{tabular}{|c|c|c|c|c|c|c|c|c|c|c|c|c|}
\hline \multirow[b]{2}{*}{ Station: } & \multicolumn{8}{|c|}{ Grid 1} & \multicolumn{4}{|c|}{ Grid 2} \\
\hline & Go05 & G009 & G013 & G017 & $\mathrm{G} 022$ & $\mathrm{G} 027$ & G032 & G036 & G093 & G098 & G105 & G112 \\
\hline \multicolumn{13}{|l|}{ Ciliates } \\
\hline Tintinnids & 100 & 50 & 200 & 50 & 0 & 250 & 100 & 50 & 50 & 100 & 150 & 100 \\
\hline Aloricates & 2050 & 1650 & 1850 & 1950 & 2100 & 2150 & 2500 & 2150 & 1250 & 1700 & 1450 & 1050 \\
\hline \multicolumn{13}{|l|}{ Dinoflagellates } \\
\hline Amphidinium sp. & 150 & 250 & 150 & 150 & 200 & 150 & 50 & 200 & 50 & 0 & 100 & 0 \\
\hline Amphisolenia sp. & 100 & 150 & 150 & 100 & 200 & 150 & 150 & 50 & 150 & 100 & 50 & 150 \\
\hline Dinophysis sp. & 0 & 0 & 250 & 50 & 0 & 50 & 150 & & 50 & 150 & 0 & 100 \\
\hline Gonyaulax sp. & 150 & 100 & 250 & 200 & 50 & 50 & 250 & 250 & 200 & 350 & 100 & 150 \\
\hline Protoperidinium sp. & 400 & 450 & 550 & 650 & 450 & 450 & 600 & 500 & 350 & 550 & 250 & 300 \\
\hline Total & 2950 & 2550 & 3150 & 3350 & 3050 & 3200 & 3650 & 3450 & 2050 & 2850 & 2100 & 1850 \\
\hline
\end{tabular}

The same 7 species were again the most abundant species along the second grid (Table 3). The abundances of these species were, however, generally higher on this occasion compared to the first grid and ranged between 5.5 and 16.4 ind $\mathrm{m}^{-3}$ (Table 3 ). As in the first grid, copepods were again the most numerous component of the zooplankton assemblages, contributing between 40 and $95 \%$ of total zooplankton counts. An exception was Stn G098, where the salp Salpa thompsoni was identified as being the most numerous species accounting for $\sim 60 \%$ of total zooplankton. Among the copepods, Metridia gerlachei and Calanoides acutus were again the most numerous. Among the larger zooplankton, the Antarctic krill Euphausia superba generally dominated. Krill densities ranged between 0.07 and 0.65 ind. $\mathrm{m}^{-3}$ (Table 3).

\section{Integrated chlorophyll}

During the first grid survey, chlorophyll concentrations above the $1 \%$ light depth were generally $<41 \mathrm{mg}$ chl a $\mathrm{m}^{-2}$ and increased from west to east (Table 4). The contribution of the $<20 \mu \mathrm{m}$ chlorophyll fraction (nano- and picophytoplankton) ranged between 60 and $74 \%$ of the total. Exceptions were Stns G027 and G032 where chlorophyll concentrations were $>50 \mathrm{mg}$ chl a $\mathrm{m}^{-2}$ (Table 4). These were dominated by microphytoplankton which comprised 62 and $66 \%$ of the total, respectively.

Along the second grid, total chlorophyll concentra-

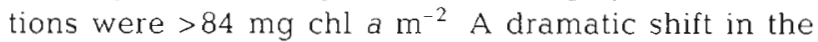
size composition of the phytoplankton assemblages was evident with large cells contributing between 54 and $71 \%$ of the total phytoplankton, dominating total chlorophyll during the entire grid (Table 4). Associated with the increase in microphytoplankton was a decrease in the contribution of the picophytoplankton to total chlorophyll. Picophytoplankton contributed $<10 \%$ of the total at all stations. The nanophytoplankton contributed between 25 and $35.5 \%$ of the total (Table 4).

\section{Integrated primary production}

Integrated primary production during the first grid showed no clear spatial patterns and ranged from 133 to $356 \mathrm{mg} \mathrm{C} \mathrm{m} \mathrm{m}^{-1}$ (Table 5). Generally, the nanophytoplankton fraction was the most important

Table 3. Mean abundances (ind. $\mathrm{m}^{-3}$ ) of the 7 most important meso- and macrozooplankton species during the repeat grid survey

\begin{tabular}{|lccccccccccccc|}
\hline Species & \multicolumn{1}{c}{ Station: } & G005 & G009 & G013 & G017 & G022 & G027 & G032 & G036 & G093 & G098 G105 & G112 \\
\hline Rhincalanus gigas & 0.96 & 0 & 0.17 & 0.53 & 1.73 & 1.74 & 0.62 & 0.23 & & 1.30 & 0.37 & 1.37 & 0.31 \\
Calanus propinquus & 0.90 & 0.20 & 0.19 & 0.61 & 1.15 & 0.39 & 0.62 & 0.47 & 1.30 & 0.19 & 1.27 & 4.97 \\
Calanoides acutus & 0.84 & 1.61 & 0.75 & 2.52 & 0.74 & 8.13 & 1.45 & 3.24 & 4.89 & 0.82 & 2.73 & 1.52 \\
Metridia gerlachei & 0.90 & 0.56 & 0.65 & 1.83 & 1.64 & 1.26 & 3.51 & 2.46 & 7.82 & 0.86 & 2.51 & 6.16 \\
Euphausia superba & 0 & 0 & 0.01 & 0 & 0 & 0.08 & 0 & 0 & 0.65 & 0.07 & 0.40 & 0.41 \\
Thysanoessa macrura & 0 & 0.02 & 0 & 0.08 & 0.14 & 0.08 & 0.01 & 0.02 & 0.26 & 0 & 0 & 0.04 \\
Salpa thompsoni & 0.06 & 0.09 & 0.45 & 0.33 & 0.46 & 0.07 & 0.25 & 0.24 & 0.20 & 3.21 & 0.20 & 0.40 \\
Total & 3.66 & 2.48 & 2.22 & 4.07 & 5.86 & 12.46 & 6.46 & 6.66 & & 16.42 & 5.50 & 8.48 & 13.45 \\
\hline
\end{tabular}


Table 4. Integrated chlorophyll a (mg chl a $\mathrm{m}^{-2}$ ) during the repeat grid survey

\begin{tabular}{|lrrrr|}
\hline \multirow{2}{*}{ Station } & \multicolumn{4}{c}{ Phytoplankton size fraction } \\
& $>20 \mu \mathrm{m}$ & $2-20 \mu \mathrm{m}$ & $<2 \mu \mathrm{m}$ & Total \\
\hline Grid 1 & & & & \\
G005 & 14.4 & 12.3 & 10.8 & 37.5 \\
G009 & 13.4 & 11.7 & 13.9 & 39.0 \\
G013 & 8.5 & 13.3 & 14.2 & 36.0 \\
G017 & 10.3 & 13.4 & 11.5 & 35.2 \\
G022 & 13.9 & 12.2 & 10.8 & 36.9 \\
G027 & 48.4 & 14.3 & 13.6 & 77.6 \\
G032 & 49.6 & 12.9 & 13.6 & 75.5 \\
G036 & 16.6 & 12.9 & 12.1 & 41.6 \\
Grid 2 & & & & \\
G093 & 75.4 & 29.5 & 11.7 & 116.6 \\
G098 & 49.9 & 25.0 & 9.4 & 84.3 \\
G105 & 46.6 & 31.3 & 10.3 & 88.2 \\
G112 & 51.4 & 29.8 & 9.9 & 91.1 \\
\hline
\end{tabular}

contributor. Exceptions were Stns G027 and G032 where the microphytoplankton, contributing 56 and $65 \%$ of total, respectively, dominated total primary production. The nanophytoplankton production ranged between 52 and $100 \mathrm{mg} \mathrm{C} \mathrm{m}^{-2} \mathrm{~d}^{-1}$ while the picophytoplankton production ranged between 19 and $55 \mathrm{mg} \mathrm{C} \mathrm{m}^{-2} \mathrm{~d}^{-1}$ (Table 5). Microphytoplankton areal production ranged between 45 and $230 \mathrm{mg} \mathrm{C} \mathrm{m}^{-2} \mathrm{~d}^{-1}$.

During the second grid, the total integrated production was significantly higher $(F=4.11 ; p<0.05)$, ranging between 263 and $400 \mathrm{mg} \mathrm{C} \mathrm{m}^{-2} \mathrm{~d}^{-1}$ (Table 5). A marked change in the contribution of the microphytoplankton to total integrated production was recorded. The contribution of the microphytoplankton production to total was the highest, ranging between 52 and $70 \%$ of the total (Table 5). The actual levels of microphytoplankton carbon uptake varied from 148 to $280 \mathrm{mg} \mathrm{C} \mathrm{m}^{-2} \mathrm{~d}^{-1}$ (Table 5). Associated with the increase in microphytoplankton production was a dramatic decrease in the absolute production rates of the picophytoplankton ( 7 to $14 \mathrm{mg} \mathrm{C} \mathrm{m}^{-2} \mathrm{~d}^{-1}$ ) which represented $<5 \%$ of the total production at all stations. The contribution of the nanophytoplankton production to total daily primary production increased, ranging between 26 and $44 \%$ (Table 5 ).

\section{Protozoan grazing}

Instantaneous growth and grazing coefficients with confidence limits derived from all the grazing experiments during the 2 grid surveys are shown in Tables 6 \& 7. In all experiments, the relationship between apparent growth rate and dilution was significantly linear ( $p<0.05$ in all cases).
Table 5. Integrated primary production $\left(\mathrm{mg} \mathrm{C} \mathrm{m}^{-2} \mathrm{~d}^{-1}\right)$ during the 2 grids occupied

\begin{tabular}{|lrrrr|}
\hline \multirow{2}{*}{ Station } & \multicolumn{4}{c}{ Size classes of phytoplankton } \\
& $>20 \mu \mathrm{m}$ & $2-20 \mu \mathrm{m}$ & $<2 \mu \mathrm{m}$ & Total \\
\hline Grid 1 & & & & \\
G005 & 62.1 & 100.1 & 55.2 & 217.3 \\
G009 & 45.2 & 52.2 & 51.2 & 148.6 \\
G013 & 44.7 & 78.3 & 35.0 & 158.0 \\
G017 & 67.2 & 93.4 & 40.1 & 200.7 \\
G022 & 106.0 & 84.9 & 37.8 & 228.7 \\
G027 & 150.9 & 72.5 & 48.9 & 271.4 \\
G032 & 229.6 & 94.6 & 32.0 & 356.2 \\
G036 & 44.5 & 69.4 & 19.0 & 132.9 \\
Grid 2 & & & & \\
G093 & 201.0 & 77.8 & 11.3 & 290.1 \\
G098 & 148.5 & 107.5 & 7.3 & 263.3 \\
G105 & 280.4 & 105.9 & 13.8 & 400.1 \\
G112 & 171.1 & 144.0 & 9.1 & 324.2 \\
\hline
\end{tabular}

During the first grid, instantaneous growth coefficients of phytoplankton $(k)$ at the surface ranged between 0.037 and $0.093 \mathrm{~d}^{-1}$ (Table 6). Instantaneous grazing coefficients of protozoans $(g)$ ranged from 0 to $0.068 \mathrm{~d}^{-1}$ (Table 6). These correspond to a loss of between 0 and $6.7 \%$ of the initial standing stock, or between 0 and $95 \%$ of the potential phytoplankton production.

The instantaneous growth coefficients at the chlorophyll maximum were lower, ranging between 0.017 and $0.084 \mathrm{~d}^{-1}$ (Table 6). The protozoan grazing coefficients ranged from 0.004 to $0.058 \mathrm{~d}^{-1}$. These rates correspond to a daily loss of between 0.5 and $31.3 \%$ of the initial phytoplankton standing stock, or between 11 and $256 \%$ of the potential phytoplankton production (Table 6).

During the second grid survey, instantaneous growth coefficients of phytoplankton in the surface waters ranged between 0.011 and $0.051 \mathrm{~d}^{-1}$ and between 0.019 and $0.047 \mathrm{~d}^{-1}$ at the chlorophyll maximum (Table 7). These rates are equivalent to between 0.016 and 0.070 chlorophyll doublings $\mathrm{d}^{-1}$ in the surface waters and between 0.027 and 0.068 doublings $\mathrm{d}^{-1}$ at the chlorophyll maximum (Table 7). The instantaneous grazing coefficients of microzooplankton on phytoplankton in the surface waters varied between 0.021 and $0.051 \mathrm{~d}^{-1}$. These rates correspond to a loss of between 0.5 and $8 \%$ of the initial standing stock or between 9.1 and $25 \%$ of the daily potential primary production (Table 7). At the chlorophyll maximum, the instantaneous grazing coefficients were higher $(0.006$ to $0.018 \mathrm{~d}^{-1}$ ) and were equivalent to a daily loss of between 0.6 and $2.6 \%$ of the initial standing stock or between 27 and $53 \%$ of the potential phytoplankton production (Table 7). 
Table 6. Rate estimates with squared regression coefficients $\left(\mathrm{r}^{2}\right)$ of chlorophyll production and microzooplankton grazing in the surface waters and at the chlorophyll maximum during the first grid survey. $P_{0}$ : initial chlorophyll concentration $(\mu \mathrm{g}$ $1^{-1}$ ) $I g$ : \% initial phytoplankton standing stock consumed; $k$ : phytoplankton growth coefficient; $g$ : microzooplankton grazing coefficient; $P g: \%$ potential primary production consumed

\begin{tabular}{|c|c|c|c|c|c|c|}
\hline Station & $r^{2}$ & $P_{0}$ & $k\left(\mathrm{~d}^{-1}\right)$ & $g\left(\mathrm{~d}^{-1}\right)$ & $\lg \left(\mathrm{d}^{-1}\right)$ & $P g\left(\mathrm{~d}^{-1}\right)$ \\
\hline \multicolumn{7}{|c|}{ Surface waters } \\
\hline G005 & 37 & 0.23 & 0.055 & - & - & - \\
\hline G009 & 32 & 0.32 & 0.042 & 0.040 & 4.1 & 94.8 \\
\hline G013 & 51 & 0.26 & 0.038 & 0.041 & 3.8 & 50.2 \\
\hline G017 & 62 & 0.28 & 0.037 & 0.064 & 6.1 & 75.1 \\
\hline G022 & 84 & 0.37 & 0.081 & 0.047 & 4.6 & 57.5 \\
\hline G027 & 58 & 0.51 & 0.038 & 0.041 & 4.1 & 46.7 \\
\hline G032 & 61 & 0.39 & 0.085 & 0.068 & 6.7 & 80.9 \\
\hline G036 & 73 & 0.29 & 0.093 & 0.054 & 5.2 & 56.5 \\
\hline \multicolumn{7}{|c|}{ Chlorophyll maximum } \\
\hline G005 & 63 & 0.41 & 0.021 & 0.041 & 0.5 & 11.5 \\
\hline G009 & 38 & 0.32 & 0.047 & 0.017 & 1.9 & 33.3 \\
\hline G013 & 71 & 0.48 & 0.026 & 0.030 & 31.3 & 90.1 \\
\hline G017 & 82 & 0.34 & 0.033 & 0.047 & 4.4 & 60.0 \\
\hline G022 & 56 & 0.35 & 0.017 & 0.046 & 4.6 & 256.0 \\
\hline G027 & 68 & 0.28 & 0.026 & 0.030 & 2.9 & 80.0 \\
\hline G032 & 71 & 0.35 & 0.065 & 0.053 & 5.1 & 82.6 \\
\hline G036 & 68 & 0.30 & 0.084 & 0.058 & 5.7 & 69.2 \\
\hline
\end{tabular}

Analysis of variance indicated that the percentage standing stock removed by protozoan grazing each day was not significantly different between the surface $(F=$ $0.57)$ and chlorophyll maximum $(F=0.63)$ during either grid survey ( $p>0.05$ in both cases). Pearson and 5 th order partial correlation coefficients between microplankton abundance, herbivory, chlorophyll concentration and temperature showed no significant relationships during the entire investigation ( $p>0.05$ in all cases).
Table 7. Rate estimates with squared regression coefficients $\left(r^{2}\right)$ of chlorophyll production and microzooplankton grazing in the surface waters and at the chlorophyll maximum during the second grid survey. $P_{0}$ : initial chlorophyll concentration ( $\mu \mathrm{g}$ $1^{-1}$ \}; Ig: \% initial phytoplankton standing stock consumed; $k$ : phytoplankton growth coefficient; g: microzooplankton grazing coefficient; $P g: \%$ potential primary production consumed

\begin{tabular}{|lcccccc|}
\hline Station & $\mathrm{r}^{2}$ & $P_{0}$ & $k\left(\mathrm{~d}^{-1}\right)$ & $g\left(\mathrm{~d}^{-1}\right)$ & $I g\left(\mathrm{~d}^{-1}\right)$ & $P g\left(\mathrm{~d}^{-1}\right)$ \\
\hline \multicolumn{5}{l}{ Surface } & waters \\
G093 & 52 & 3.39 & 0.011 & 0.021 & 8.2 & 25.0 \\
G098 & 47 & 1.10 & 0.025 & 0.041 & 0.5 & 11.7 \\
G105 & 76 & 0.98 & 0.051 & 0.051 & 0.5 & 9.8 \\
G112 & 63 & 0.86 & 0.038 & 0.028 & 0.4 & 9.1 \\
Chlorophyll maximum & & & & \\
G093 & 69 & 0.97 & 0.019 & 0.006 & 0.6 & 32.3 \\
G098 & 86 & 0.65 & 0.037 & 0.018 & 1.9 & 53.1 \\
G105 & 48 & 0.73 & 0.047 & 0.016 & 2.6 & 34.3 \\
G112 & 57 & 0.81 & 0.045 & 0.012 & 1.2 & 27.0 \\
\hline
\end{tabular}

\section{Meso- and macrozooplankton grazing impact}

The community grazing impact of the 7 most abundant meso- and macrozooplankton species along the 2 grids is shown in Table 8. During the first grid survey, the total ingestion rate varied from 0.07 to $0.61 \mathrm{mg}$ pigm. $\mathrm{m}^{-2} \mathrm{~d}^{-1}$ (mean $=0.35 \mathrm{mg}$ pigm. $\left.\mathrm{m}^{-2} \mathrm{~d}^{-1}\right)$ (Table 8$)$. These ingestion rates correspond to between 0.2 and $1.7 \%$ of the total integrated chlorophyll biomass or between 10 and $30 \%($ mean $=18.7 \%)$ of the daily phytoplankton production (Table 8). Among the grazers, copepods were the most important, consuming between 46 and $75 \%$ of total pigment consumed daily.

During the second grid survey, the community grazing impact was substantially but not significantly higher $(\mathrm{p}>0.05)$ than during the first one, with the

Table 8. Phytoplankton biomass, production, ingestion rates and grazing impact of the 7 most important zooplankton species along the 2 repeat grid surveys

\begin{tabular}{|c|c|c|c|c|c|}
\hline \multirow[t]{2}{*}{ Station } & \multirow{2}{*}{$\begin{array}{l}\text { Phytoplankton biomass } \\
\text { (mg chl a } \mathrm{m}^{-2} \text { ) }\end{array}$} & \multirow{2}{*}{$\begin{array}{l}\text { Primary production } \\
\left(\mathrm{mg} C \mathrm{~m}^{-2} \mathrm{~d}^{-1}\right)\end{array}$} & \multirow{2}{*}{$\begin{array}{l}\text { Daily ingestion } \\
\left.\text { (mg pigm. } \mathrm{m}^{-2}\right)\end{array}$} & \multicolumn{2}{|c|}{ Daily grazing impact } \\
\hline & & & & $\begin{array}{l}\% \text { phytoplankton } \\
\text { standing stock }\end{array}$ & $\begin{array}{l}\% \text { daily primary } \\
\text { production }\end{array}$ \\
\hline \multicolumn{6}{|l|}{ Grid 1} \\
\hline G005 & 37.5 & 217.3 & 0.34 & 0.90 & 19.1 \\
\hline G009 & 39.0 & 148.6 & 0.21 & 0.53 & 20.9 \\
\hline G013 & 36.0 & 158.0 & 0.07 & 0.20 & 10.3 \\
\hline G017 & 35.2 & 200.7 & 0.61 & 1.73 & 29.6 \\
\hline $\mathrm{G} 022$ & 36.9 & 228.7 & 0.33 & 0.89 & 18.0 \\
\hline G027 & 77.6 & 271.4 & 0.56 & 0.72 & 20.7 \\
\hline G032 & 75.5 & 356.2 & 0.36 & 0.47 & 20.7 \\
\hline G036 & 41.6 & 132.9 & 0.21 & 0.50 & 15.3 \\
\hline \multicolumn{6}{|l|}{ Grid 2} \\
\hline G093 & 116.6 & 290.1 & 0.87 & 0.74 & 25.3 \\
\hline G098 & 84.3 & 263.3 & 2.15 & 2.55 & 48.1 \\
\hline G105 & 88.2 & 400.1 & 0.66 & 0.75 & 15.6 \\
\hline G112 & 91.1 & 324.2 & 1.07 & 1.18 & 25.7 \\
\hline
\end{tabular}


total daily pigment ingested ranging between 0.66 and $2.15 \mathrm{mg}$ pigm. $\mathrm{m}^{-2} \mathrm{~d}^{-1}$ (mean $=0.85 \mathrm{mg}$ pigm. $\mathrm{m}^{-2} \mathrm{~d}^{-1}$ ). These rates correspond to between 0.7 and $2.6 \%$ (mean $=1.1 \%)$ of the integrated phytoplankton biomass and between 16 and $48 \%$ (mean $=28.7 \%$ ) of the total primary production per day (Table 8 ). Of the 2 size classes, macrozooplankton were the most important grazers at Stns G093 and G098 where they accounted for 60 and $95 \%$ of total pigment consumption, respectively. In contrast, at Stns G105 and G112, copepods were the most important grazers of phytoplankton accounting for 72 and $84 \%$ of total pigment consumption, respectively.

\section{DISCUSSION}

The changes in the general oceanographic conditions during this investigation are consistent with the development of a summer melt water structure, including the development of well-defined halo-and thermoclines in the upper $50 \mathrm{~m}$ of the water column (Fig. 3). Also, the increase in water temperature during the second grid survey suggests that summer capping of colder winter waters had occurred. These changes were accompanied by shifts in the phyto- and zooplankton community structure and subsequent partitioning of carbon between the various size classes of herbivores.

A shift in the size composition of the phytoplankton assemblages was evident from a community dominated by nano- and picophytoplankton $(<20 \mu \mathrm{m})$ during the first grid to one dominated by microphytoplankton (>20 $\mu \mathrm{m}$ ) during the second grid (Table 4). The nano- and picophytoplankton dominated phytoplankton community of the first grid survey represents the typical situation found in the Southern Ocean during austral winter (Garrison et al. 1991, 1993, Kang \& Fryxell 1993, Kivi \& Kuosa 1994, Froneman \& Perissinotto 1996a). Associated with the shift in community size structure was an increase in the chlorophyll concentration, resulting from a dramatic increase in microphytoplankton and, to a lesser extent, nanophytoplankton concentrations (Table 4). The predominance of typical ice-associated microphytoplankton species such as Chaetoceros spp. and Nitzschia spp. (Heywood \& Whitaker 1984, Horner 1985) during the second grid suggests that the microphytoplankton were released during the ice melt.

During the first grid survey, total areal production ranged between 133 and $356 \mathrm{mg} \mathrm{C} \mathrm{m}^{-2} \mathrm{~d}^{-1}$ (Table 5). These rates are amongst the lowest recorded in the Southern Ocean (Mitchell \& Holm-Hansen 1991, Laubscher et al. 1993). According to Kirk (1994), photo-inhibition is likely to be of significance in water bodies of high solar irradiance and low wind speeds. An indication of the physiological status of algal assemblages can be derived from the photosynthetic capacity $\left(P^{B}\right)$ values of the phytoplankton assemblages (von Bodungen et al. 1988). During the first grid survey, the $P^{B}$ values of phytoplankton in the upper $20 \mathrm{~m}$ of the water column ranged between 0.02 and $0.39 \mathrm{mg} \mathrm{C}(\mathrm{mg} \mathrm{chl} \mathrm{a})$ $\mathrm{h}^{-1}$, well below the average $P^{B}$ values recorded for Antarctic phytoplankton [range 0.8 to $8 \mathrm{mg} \mathrm{C}$ (mg chl a) $\mathrm{h}^{-1}$ I (Tilzer et al. 1986, Laubscher et al. 1993). The low $P^{B}$ values recorded during the first grid provide partial evidence of light inhibition of phytoplankton production during the first grid survey. Lancelot et al. (1993) suggested that at ice cover $>40 \%$, phytoplankton production would be reduced due to light limitation. However, during the first grid survey the highest production rates were recorded at stations which had the highest ice cover (Tables 1 \& 5), providing further support for the hypothesis of photoinhibition in the winter phytoplankton assemblages.

Total areal phytoplankton production rates along the second grid ranged between 263 and $400 \mathrm{mg} \mathrm{C} \mathrm{m}^{-2} \mathrm{~d}^{-1}$ (Table 5). Despite the evidence of induced water column stability (well-developed halo- and thermocline), the production rates, although higher than along the first grid, are still among the lowest recorded in the MIZ (Mitchell \& Holm-Hansen 1991, Laubscher et al. 1993, Boyd et al. 1995). This suggests that while water column stability appears to be a pre-requisite for an increased in situ phytoplankton production, other factors must also play an important role in determining phytoplankton production rates at the MIZ. It is widely accepted that nutrient limitation, with the exception of silicate, plays no role in Antarctic phytoplankton production (Jacques 1989). During this investigation, silicate concentrations were always $>61 \mu \mathrm{mol} \mathrm{l}^{-1}$, above the threshold for the dominant diatom species during this investigation (Jacques 1983, 1989). Nutrient availability did not, therefore, appear to be limiting phytoplankton growth during this investigation. Iron limitation in open waters may also inhibit phytoplankton growth in the Southern Ocean (Martin et al. 1990). However, the close proximity of the second grid to the continental shelf suggests that iron was probably not limiting phytoplankton production during our study. It appears, therefore, that the low production rates recorded during the second grid are the result of a combination of factors rather than any single one.

The microplankton assemblages found during this investigation were entirely dominated by protozoans with densities ranging between 1650 and $2850{\text { cells } l^{-1}}^{-1}$ (Table 2). Our estimates of abundance are in the same range as those obtained in a recent study conducted in the MIZ of the Bellingshausen Sea (Burkill et al. 1995). In a review article, Garrison (1991) suggested that typ- 
ical densities of larger protozooplankton in Antarctic waters range between $10^{2}$ and $10^{3}$ cells $\mathrm{l}^{-1}$. The high microplankton densities recorded during this study probably reflect the higher chlorophyll concentrations typically associated with the retreating ice (El-Sayed 1988, Jacques 1989). Indeed, during this study, microplankton densities were strongly correlated to nano- and picophytoplankton concentrations $(p<0.05$ in both cases). The decrease in microplankton densities during the second grid survey probably results from both a decrease in the avallability of their preferred food particles, i.e. picophytoplankton (Hansen et al. 1994, Peters 1994), or predation by larger zooplankton species (Froneman et al. 1996). It should be pointed out, however, that the use of Lugol's solution to fix the microplankton samples may have resulted in the underestimation of the contribution of dinoflagellates to total cell counts (James 1991, Leakey et al 1994). Also, we were unable to differentiate between the autotrophic and heterotrophic components of the microplankton assemblages. However, in a previous study using epifluorescent techniques we have shown that $<25 \%$ of the protozoans counted could be considered mixotrophic or autotrophic (Froneman \& Perissinotto 1996a).

The protozoan grazing impact on phytoplankton during the repeat grid survey showed a strong temporal pattern (Tables $6 \&$ 7). During the first grid, when small phytoplankton cells $(<20 \mu \mathrm{m})$ dominated total chlorophyll biomass, protozoans removed on average $71 \%$ of the potential phytoplankton production compared to $23 \%$ of the potential production removed during the second grid when microphytoplankton dominated the total biomass (Tables $6 \&$ 7). The high grazing impact of the protozoans recorded during this study are consistent with results obtained in similar studies conducted in other MIZs throughout the Southern Ocean (Garrison et al. 1993, Burkill et al. 1995, Froneman et al. 1996a). Our results are, however, in direct conflict with those of Mathot et al. (1992) and Burkill et al. (1995) which showed that the highest grazing impact of protozoans in the MIZ is associated with open waters. Differences in the results can probably be related to the size structure of the primary producers. Our results show that grazing by protozoans is sufficient to check the growth of phytoplankton only when small phytoplankton cells $(<20 \mu \mathrm{m})$ dominate total chlorophyll. This is consistent with the results obtained in a similar study conducted in the MIZ of the Weddell Sea which showed that grazing by protozoans was sufficient to control the development of an iceedge phytoplankton bloom dominated by nano- and picophytoplankton (Lancelot et al. 1993). The increase in the contribution of the microphytoplankton was, however, accompanied by a dramatic decrease in the grazing impact of the protozoans (Table 7). The inability of protozoans to feed on microphytoplankton appears to reflect morphological constraints.

Along both grids the zooplankton communities were dominated by common high Antarctic copepods, (mostly Calanoides acutus and Metridia gerlachei) which accounted for between 60 and $98 \%$ of total zooplankton (Table 3). The species composition and estimates of zooplankton abundance during this study compare well with those obtained in previous studies conducted in the Southern Ocean (Conover \& Huntley 1991, Voronina et al. 1994, Atkinson \& Shreeve 1995). Although it is traditionally thought that the Antarctic krill Euphausia superba is the most important component of the zooplankton assemblage in the region of the Antarctic Slope Front (Pakhomov 1995), densities of krill were always $<0.7$ ind. $\mathrm{m}^{-3}$ during this study (Table 3). The low densities of E. superba during this survey were probably related to the presence of large numbers of salps, mainly Salpa thompsoni, in the area. Previous studies have shown these 2 species are often spatially segregated (Pakhomov 1993). Our results are consistent with recent studies which have shown that copepods can be regarded as the most important component of the zooplankton assemblage in the high Antarctic (Voronina et al. 1994, Voronina in press). Indeed, using a data set spanning more than $20 \mathrm{yr}$. Voronina (in press) has shown that copepods account for $>93 \%$ of the total zooplankton production in the Southern Ocean. Although it is well documented that the larger zooplankton species reach their maximum biomass later during summer than copepods (Voronina et al. 1994), no such increase was evident during the second grid survey. Amongst the larger zooplankton the tunicate $S$. thompsoni was generally the most abundant (Table 3). Recent studies conducted in the vicinity of the MIZ have shown that, at times, S. thompsoni may be the most abundant component of the zooplankton assemblages (Perissinotto \& Pakhomov in pressj.

The grazing impact of the 7 most abundant zooplankton species increased from an average $19 \%$ of daily primary production during the first grid survey to $-29 \%$ during the second grid (Table 8 ). These results are in general agreement with the findings of other zooplankton grazing studies conducted during seasonal ice retreat in the Bellingshausen Sea (Atkinson \& Shreeve 1995). The elevated grazing impact observed during the second grid is the result of an increase in zooplankton abundance which coincided with an increase in microphytoplankton concentrations. On this occasion, the correlation between zooplankton abundance and microphytoplankton was highly significant $\left(\mathrm{r}^{2}=0.74, \mathrm{p}<0.05\right)$. Shifts in the community structure of the zooplankton assemblages may also have 
contributed to the increased grazing impact during the second grid. For example, Metridia gerlachei, the dominant zooplankton species during the second survey, has been shown to have both the highest growth coefficients and the highest daily rations amongst the 4 copepod species examined during this survey (Conover \& Huntley 1991). Similarly, the highest grazing impact ( $48 \%$ of daily production) during the entire investigation was recorded at Stn G098, where the tunicate Salpa thompsoni dominated total zooplankton (Table 8). This species has been shown to have a very high grazing impact, becoming at times the most important consumer of phytoplankton production in the zooplankton assemblages of the Southern Ocean (Perissinotto \& Pakhomov in press).

During the first grid survey, grazing impact of the protozoans was sufficient at times to control the growth of phytoplankton when it was dominated by nanophytoplankton (Table 6). The microzooplankton grazing studies were, however, conducted in the absence of potential predators such as copepods, krill and salps. Carnivory by larger zooplankton on microzooplankton is well documented (Hopkins \& Torres 1988, 1993, Atkinson 1995, Froneman et al. in 1996b). Feeding rates of larger zooplankton on protozoans can be expected to be high in regions dominated by small phytoplankton cells, since larger zooplankton are unable to feed efficiently on food particles $<2 \mu \mathrm{m}$ (Stoecker \& Capuzzo 1990, Fortier et al. 1994). Our estimates of protozoan grazing impact can, therefore, be regarded as overestimated. It should be noted that trophic cascading resulting from the increased predation impact of the larger protozoans on the nanoheterotrophs in the absence of large zooplankton may cause a shift in the community structure (Wickham 1995).

In conclusion, the results of this study show that during ice melt a shift in the partitioning of carbon in the planktonic food web was mediated by a change in the size structure of the phytoplankton assemblages. During early spring when small cells $(<20 \mu \mathrm{m})$ dominated the total chlorophyll, protozoans represented the most important grazers and were at times able to control the growth of phytoplankton. A shift in the size composition of the phytoplankton assemblages associated with the release of epontic cells during ice melt was associated with the larger zooplankton becoming the most important grazers of phytoplankton production. The grazer-mediated downward flux during the 2 grid surveys can be crudely estimated assuming firstly, that protozoans do not contribute to vertical flux; secondly, that the meso- and macrozooplankton have an average assimilation efficiency of $70 \%$; and finally, that the unconsumed primary production (proportion of primary production not consumed by protozoans and larger zooplankton) settles to depth. Using the mean values presented in Tables 6 to 8 , the grazer-mediated carbon downward flux was calculated to be equivalent to $-35 \%$ of the primary production during Grid 1 and $\sim 15 \%$ during Grid 2. This result shows that although the highest grazing impacts of larger zooplankton were recorded during the second grid, the efficiency of the grazer-mediated biological pump was twice as efficient during the first grid. Furthermore, the result also shows that the sinking of phytoplankton cells, particularly during the second grid survey, represented the most important mechanism for the transfer of carbon from the surface waters to depth. This result is consistent with a previous study conducted in the Weddell Sea which showed that maximum particle flux rates coincided with the retreat of sea ice (Fischer et al. 1988).

Acknowledgements. We thank the Department of Environmental Affairs \& Tourism for providing funds and facilities for this study. We are particularly grateful to the master and crew of the MV 'SA Agulhas' for their co-operation. We also thank Dr M. I. Lucas from the University of Cape Town for allowing us to use his unpublished nutrient data. Finally, we express our gratıtude to K. Neke, S. Ross, Z. Davidson, D. Barraclough and $D$. Weeks for their invaluable assistance at sea and to Val Meaton for identifying and enumerating the diatoms.

\section{LITERATURE CITED}

Almgren T, Dyrssen D, Fonselius S (1983) Determination of alkalinity and total carbonate. In: Grasshoff $K$, Ehrhardt $M$, Kremling K (eds) Methods of seawater analysis. Verlag Chemie, Weinheim, p 99-123

Atkinson A (1995) Omnivory and feeding selectivity in five copepod species during spring in the Bellingshausen Sea, Antarctıca. J Mar Sci 52:385-396

Atkinson A, Shreeve RS (1995) Response of the copepod community to a spring bloom in the Bellingshausen Sea. Deep Sea Res II 42:1291-1312

Baars MA, Helling GR (1985) Methodical problems in the measurement of phytoplankton ingestion rate by gut fluorescence. Hydrobiol Bull 19:81-88

Berman T, Kimor B (1983) A large scale filtration apparatus for net plankton sampling. J Plankton Res 5:111-116

Boyd PW, Robinson C, Savidge G, Williams PJ leB (1995) Water column and sea-ice production during austral spring in the Bellingshausen Sea. Deep Sea Res II 42: $1177-1200$

Burkill PH, Edwards ES, Sleigh MA (1995) Microzooplankton and their role in controlling phytoplankton growth in the marginal ice zone of the Bellingshausen Sea. Deep Sea Res II 42:1277-1290

Cadee GC, Gonzalez H, Schnack-Schiel SB (1992) Krill diet affects faecal settling. Polar Biol 12:75-80

Conover RJ, Huntley M (1991) Copepods in ice covered seas - distribution, adaptations to seasonally limited food, metabolism, growth patterns and life cycle strategies in polar seas. J Mar Syst 2:1-41

Conover RL, Durvasula R, Roy S, Wang R (1986) Probable loss of chlorophyll-derived pigments during passage through 
the gut of zooplankton and some of the consequences Limnol Oceanogr 31:878-887

Elbrächter M (1991) Faeces production by dinoflagellates and other small flagellates. Mar Microb Food Webs 5:189-204

El-Sayed SZ (1988) Productivity in the Southern Ocean: a closer look. Comp Biochem Physiol 90:489-498

Fischer G, Futterer D, Gersonde R, Honjo S, Ostermann D, Wefer $G$ (1988) Seasonal variability of particle flux in the Weddell Sea and its relation to ice cover Nature 335: $426-428$

Fortier L, Le Fevre J, Legendre L (1994) Export of biogenic carbon to fish and the deep ocean: the role of large planktonic microphages. J Plankton Res 16:809-839

Froneman PW, Perissinotto R (1996a) Structure and grazıng of the microzooplankton communities of the Subtropical Convergence and a warm-core eddy in the Atlantic sector of the Southern Ocean. Mar Ecol Prog Ser 135:237-245

Froneman PW, Perissinotto R (1996b) Microzooplankton grazing and protozooplankton community structure in the south Atlantic and Atlantic sector of the Southern Ocean. Deep Sea Res 43:703-721

Fronemann PW, Perissinotto R, McQuaid (1996a) Dynamics of microplankton communities at the ice edge zone of the Lazarev Sea during a summer drogue study. J Plankton Res 18:1455-1570

Froneman PW, Pakhomov EA, Perissinotto R, McQuaid CD (1996b) Role of microzooplankton in the diet and daily ration of Antarctic zooplankton species during austral summer. Mar Ecol Prog Ser 143:15-23

Garrison DL (1991) An overview of the abundance and role of protozooplankton in Antarctic waters. J Mar Syst 2: $317-331$

Garrison DL, Buck KR, Gowing MM (1991) Plankton assemblages in the ice edge zone of the Weddell Sea during austral winter. J Mar Syst 2:123-130

Garrison DL, Buck KR, Gowing MM (1993) Winter plankton assemblage in the ice edge zone of the Weddell and Scotia Seas: composition, biomass and spatial distributions. Deep Sea Res II 40:311-338

Gonzalez HE (1992a) The distribution and abundance of krill faecal material and oval pellets in the Scotia and Weddell Seas (Antarctica) and their role in particle flux. Polar Biol $12: 81-91$

Gonzalez HE (1992b) Distribution and abundance of minipellets around the Antarctic peninsula. Implications for protistan feeding behaviour Mar Ecol Prog Ser 90: $223-236$

Granéli E, Granéli W, Rabbani MM, Daugbjerg N, Fransz G, Cuzin-Roudy J, Alder VA (1993) The influence of copepod and krill grazing on the species composition of phytoplankton communities from the Scotia-Weddell Sea. Polar Biol 13:201-213

Hansen B, Berggreen VC, Tande KS, Eilersten HC (1990) Post bloom grazing by Calanus glacialus, C. finmarchicus and C. hyperboreus in the region of the Polar Front, Barents Sea. Mar Biol 104:5-14

Hansen B, Bjornsen PK, Hansen PJ (1994) The size ratio between planktonic predators and their prey. Limnol Oceanogr 39(2):395-403

Hewes CD, Sakshaug E, Reid FMH, Holm-Hansen O (1990) Microbial autotrophic and heterotrophic eucaryotes in Antarctic waters: relationships between biomass and chlorophyll, adenosine triphosphate and particulate organic carbon. Mar Ecol Prog Ser 63:27-35

Heywood RB, Whitaker TM (1984) Marine flora. In: Laws RM (ed) Antarctic ecology, Vol 2. Academic Press, London, p $373-419$
Holm-Hansen O, Riemann B (1978) Chlorophyll-a determination: improvements in methodology. Olkos 30:438-447

Hopkins TL, Ainley DG, Torres JJ, Lancraft TM (1993) Trophic structure in open waters of the marginal ice zone in the Scotia-Weddell confluence region during spring (1983). Polar Biol 13:389-397

Hopkins TL, Torres JJ (1989) Midwater food web in the vicınity of a marginal ice zone in the western Weddell Sea Deep Sea Res 36:543-560

Horner RA (1985) Sea ice biota. CRC Press, Boca Raton

Jacques $G$ (1983) Some ecophysiological aspects of Antarctic phytoplankton. Polar Biol 2:27-33

Jacques G (1989) Primary production in the open Antarctic Ocean during austral summer. A review. Vie Milieu 39:1-17

James MR (1991) Sampling and preservation methods for the quantitative enumeration of microzooplankton. NZ J Mar Freshwater Res 25:305-310

JGOFS (1990) Core measurement protocols: reports of the core measurement working groups. Scientific Committee on Oceanic Research, Carqueiranne, Report No. 6

Kang SH, Fryxell GA (1993) Phytoplankton in the Weddell Sea, Antarctica: composition, abundance and distribution in the water-column assemblages of the marginal ice-edge zone during austral autumn. Mar Biol 116:335-348

Kurk JTO (1994) Light \& photosynthesis in aquatic ecosystems. Cambrige University Press, Cambridge

Kivi K, Kuosa H (1994) Late winter microbial communities in the western Weddell Sea (Antarctica). Polar Biol 14: 389-399

Lancelot C, Mathot S, Veth C, de Baar H (1993) Factors controlling phytoplankton ice-edge blooms in the marginal ice zone of the northwest Weddell Sea during ice retreat 1988: field observations and mathematical modelling Polar Res 13:377-387

Landry MR, Hassett RP (1982) Estimating the grazing impact of marine microzooplankton. Mar Biol 67:283-288

Laubscher RK, Perissinotto R, McQuaid CD (1993) Phytoplankton production and biomass at frontal zones in the Atlantic sector of the Southern Ocean. Polar Biol 13:471-481

Leakey JG, Burkill PH, Sleigh MA (1994) A comparison of fixatives for the estimation of abundance and biovolume of marine planktonic ciliate populations. J Plankton Res 16 : $375-389$

Legendre L, Legendre P (1983) Numerical ecology. Elsevier Scientific Publsshing Company, Amsterdam

Longhurst AR (1991) Role of the marne biosphere in the global carbon cycle. Limnol Oceanogr 36(8):1507-1526

Longhurst AR, Harrison WG (1989) The bıological pump: profiles of plankton production and consumption in the upper ocean. Prog Oceanogr 22:47-123

Mackas D, Bohrer R (1976) Fluorescence analysis of zooplankton gut contents and an investigation of diel feeding patterns. J Exp Mar Biol Ecol 25:77-85

Martin JH, Gordon RM, Fitzwater SE (1990) Iron in Antarctic waters. Nature 345:156-158

Mathot S, Dandoss JM, Lancelot C (1992) Gross and net primary production in the Weddell-Scotia Sea sector of the Southern Ocean during spring 1988. Polar Biol 12:321-332

Michaels AF, Silver MW (1988) Primary production, sinking fluxes and the microbial food web. Deep Sea Res 35: $473-490$

Mitchell BG, Holm-Hansen O (1991) Observations and modelling of the Antarctic phytoplankton crop in relation to mixing depth. Deep Sea Res 38:981-1007

Mostert SA (1983) Procedures used in South Africa for the automatic photometric determination of micro-nutrients in seawater. J Mar Sci 1:189-198 
Nöthig E, von Bodungen B (1989) Occurrence and vertical flux of faecal pellets of probably protozoan origin in the southeastern Weddell Sea (Antarctica). Mar Ecol Prog Ser $56: 281-289$

Pakhomov EA (1993) Vertical distribution and diurnal migrations of Antarctic macroplankton. In: Voronina NM (ed) Pelagic ecosystems of the Southern Ocean. Nauka Press, Moscow, p 146-150 (in Russian)

Pakhomov EA (1995) Demographic studies of Antarctic krill Euphausia superba in the Cooperation and Cosmonaut Seas (Indian sector of the Southern Ocean). Mar Ecol Prog Ser 119:45-61

Parsons TR, Maita Y, Lalli CM (1984) A manual of chemical and biological methods for seawater analysis. Pergamon Press, Oxford

Perissinotto R (1992) Mesozooplankton size selectivity and grazing impact on the phytoplankton community of the Prince Edward Archipelago (Southern Ocean). Mar Ecol Prog Ser 79:243-258

Perissinotto R, Pakhomov EA. (1996) Gut evacuation rates and pigment destruction in the Antarctic krill Euphausia superba. Mar Biol 125:47-54

Perissinotto R, Pakhomov EA (in press) The trophic role of the tunicate Salpa thompsoni in the Antarctic marine ecosystem. J Mar Syst

Peters F (1994) Prediction of planktonic protistan grazing rates. Limnol Oceanogr 39:195-206

Reid FMH (1983) Biomass estimation on components of the marine nanoplankton and picoplankton by the Utermöh] settling technique. J Plankton Res 5:235-252

Roman ML, Dam HG, Gauzens AL. Napp JM (1993) Zooplankton biomass and grazing at the JGOFS Sargasso Sea time series station. Deep Sea Res 40:883-901

Schnack SB (1985) A note on the sedimentation of particulate matter in Antarctic waters during summer. Meeresforschung 30:306-315

Sherr E, Sherr B (1988) Role of microbes in pelagic food webs: a revised concept. Limnol Oceanogr 33(5): $1225-1227$

Smith WO, Nelson DM (1986) Importance of ice edge phytoplankton production in the Southern Ocean. Bio Sci 36 : $251-256$

This article was submitted to the editor
Smith WO, Sakshaug E (1990) Polar phytoplankton. In: Smith WO (ed) Polar oceanography. Academic Press, San Diego, p $477-526$

Sokal FJ, Rohlf RR (1969) Statistical tables. Freeman \& Co, San Francisco

Statgraphics (1992) Statistical Graphics Corporation. Manugistics Inc, Rockville

Stoecker DK, Capuzzo JM (1990) Predation on protozoa: its importance to zooplankton. J Plankton Res 12:891-908

Stoecker DK, Gifford DJ, Putt M (1994) Preservation of marine planktonic ciliates: losses and cell shrinkage during fixation. Mar Ecol Prog Ser 110:293-299

Strickland JDH, Parsons TR (1968) A practical handbook of seawater analysis. Bull Fish Res Bd Can 167:1-311

Sullivan CW, Arrigo KR, McClain CR, Comiso JC, Firestone J (1993) Distribution of phytoplankton blooms in the Southern Ocean. Science 262:1832-1837

Tilzer MM, Elbrächter M, Gieskes WW, Beese B (1986) Light temperature interactions in the control of photosynthesis in Antarctic phytoplankton. Polar Biol 5:105-111

von Bodungen $B$, Nöthig EV, Sui $Q(1988)$ New production of phytoplankton and sedimentation during summer 1985 in the south eastern Weddell Sea. Comp Biochem Physiol 90. $475-487$

von Bodungen B, Smetacek VS, Tilzer MM, Zeitzschel B (1986) Primary production and sedimentation during spring in the Antarctic Peninsula region. Deep Sea Res 33:177-194

Voronina NM (in press) Comparative abundance and distribution of major suspension-feeders in the Antarctic pelagic zone. J Mar Syst

Voronina NM, Kosobokova KN, Pakhomov EA (1994) Composition and biomass of summer metazoan plankton in the $0-200 \mathrm{~m}$ layer of the Atlantic sector of the Antarctic. Polar Biol 14:91-95

Ward P, Atkinson A, Murray AWA, Wood AG, Williams R Poulet SA (1995) The summer zooplankton community at South Georgia: biomass, vertical migration and grazing. Polar Biol 15:195-208

Wickham SA (1995) Trophic relations between cyclopoid copepods and ciliated protists: complex interactions link the microbial and classic food webs. Limnol Oceanogr 40 : $1173-1181$

Manuscript first received: August 29, 1996

Revised version accepted: December 30, 1996 